\title{
AGC-1 PIE Experimental Plan
}

\author{
Tim Burchell
}

Oak Ridge National Laboratory

March 2012

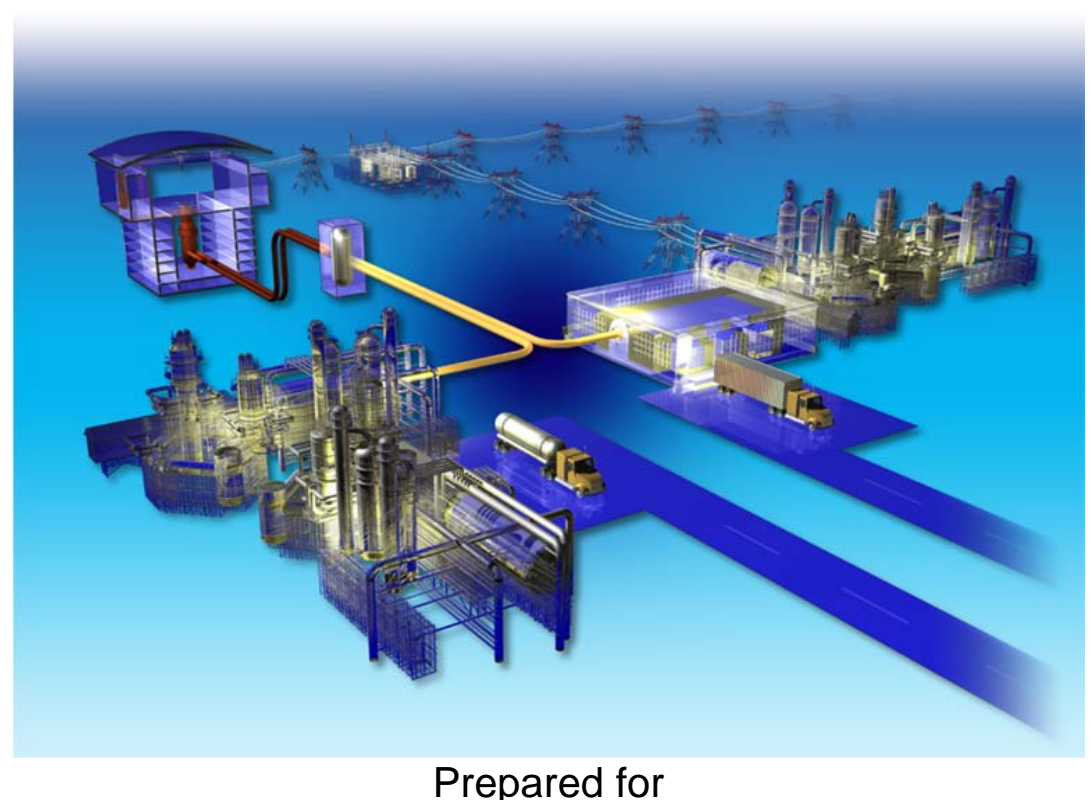

Office of Nuclear Energy Science and Technology

Prepared by

OAK RIDGE NATIONAL LABORATORY

Oak Ridge, Tennessee 37831

managed by

UT-BATTELLE, LLC

for the

U.S. DEPARTMENT OF ENERGY

under DOE Contract No. DE-AC05-00OR22725

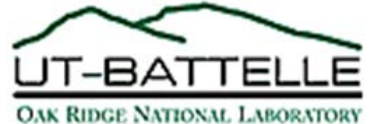

This document has been reviewed and is determined to be APPROVED FOR PUBLIC RELEASE. 
ORNL/TM-2012/70

This report was prepared as an account of work sponsored by an agency of the United States

Government. Neither the United States government nor any agency thereof, nor any of their employees, makes any warranty, express or implied, or assumes any legal liability or responsibility for the accuracy, completeness, or usefulness of any information, apparatus, product, or process disclosed, or represents that its use would not infringe privately owned rights. Reference herein to any specific commercial product, process, or service by trade name, trademark, manufacturer, or otherwise, does not necessarily constitute or imply its endorsement, recommendation, or favoring by the United States Government or any agency thereof. The views and opinions of authors expressed herein do not necessarily state or reflect those of the United States Government or any agency thereof. 


\title{
AGC-1 PIE Experimental Plan
}

\author{
Tim Burchell \\ Oak Ridge National Laboratory
}

March 2012

\author{
Prepared for \\ Office of Nuclear Energy Science and Technology \\ Prepared by \\ OAK RIDGE NATIONAL LABORATORY \\ Oak Ridge, Tennessee 37831 \\ managed by \\ UT-BATTELLE, LLC \\ for the \\ U.S. DEPARTMENT OF ENERGY \\ under DOE Contract No. DE-AC05-000R22725
}




\section{ACKNOWLEDGEMENTS}

This work is sponsored by the U.S. Department of Energy, Office of Nuclear Energy Science and Technology under contact DE-AC05-00OR22725 with Oak Ridge National Laboratories managed by UT-Battelle, LLC. 


\section{SUMMARY}

Here we report the Post-Irradiation Examination planned for the AGC-1 creep samples. The key data obtained for each grade of graphite included in the AGC-1 capsule are:

- Dimensions, volume, mass and density changes

- Creep strain

- Electrical resistivity

- Elastic constants (E, G, v) from sonic velocity

- Dynamic modulus (from fundamental frequency of vibration)

- Coefficient of thermal expansion

- Microstructural characterization

- Fracture strength

The effect of creep strain on the above properties will be determined.

These data are critical to the design of the Next Generation Nuclear Plant (NGNP). Moreover, the data supports ongoing work in the area of model development, e.g., irradiation effects models such as dimensional change and creep. The data will be used to help underpin the existing American Society of Mechanical Engineers (ASME) design code for graphite core components. 


\section{CONTENTS}

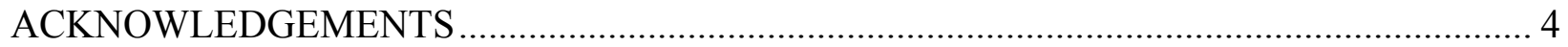

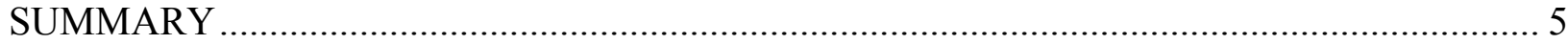

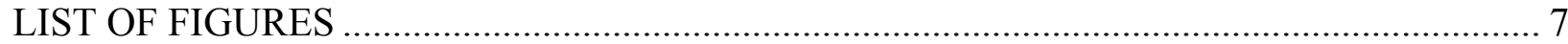

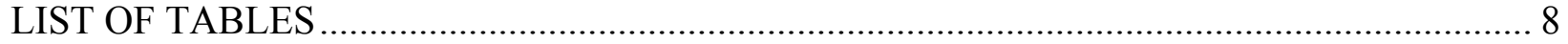

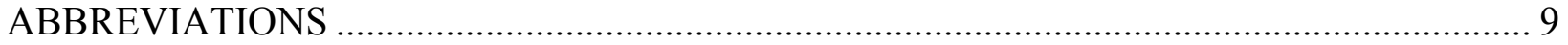

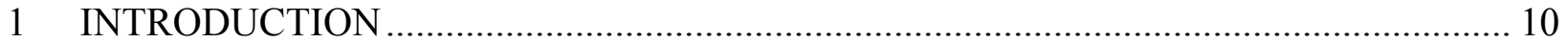

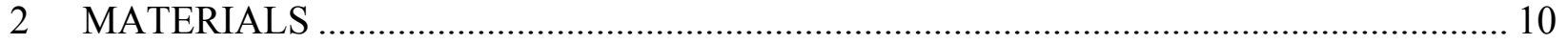

3 MATERIAL POST-IRRADIATION EXAMINATION ..................................................... 10

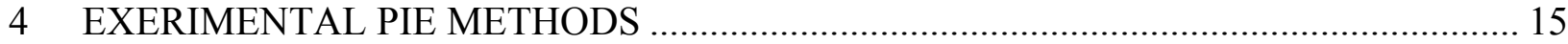

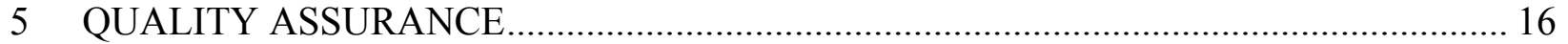

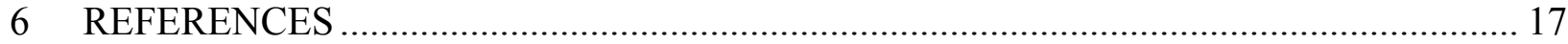

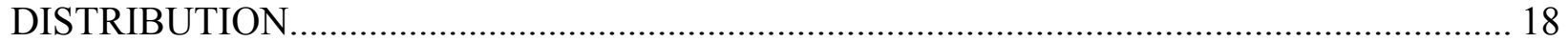




\section{LIST OF FIGURES}

Figure 1 Post-irradiation data process flow chart for AGC-1 graphites ........................................ 11

Figure 2 Drawing of AGC-1 capsule showing positions of SiC temperature monitors ............... 13

Figure 3 AGC-1 creep specimen measurement scheme ………………………………........... 16 


\section{LIST OF TABLES}

Table 1 Graphite grades and marking codes used for the AGC-1 series of creep specimens ...... 10 Table 2 Annealing schedule for $\mathrm{SiC}$ temperature monitors ............................................... 12

Table $3 \mathrm{SiC}$ temperature monitor information from AGC-1 (10-26-11) as supplied by INL ...... 14

Table 4 Applicable ASTM test methods.............................................................................. 15 


\section{ABBREVIATIONS}

AGC Advanced Graphite Creep

ASME American Society of Mechanical Engineers

ASTM American Society for Testing and Materials

ATR Advanced Test Reactor

ER Electrical Resistivity

INL Idaho National Laboratory

LAMDA Low Activation Materials Development and Analysis

MFC Materials and Fuels Complex

ORNL Oak Ridge National Laboratory

PIE Post-Irradiation Examination

Pre-IE Pre-Irradiation Examination 
ORNL/TM-2012/70

\section{INTRODUCTION}

The AGC-1 experiment is the first of a series of graphite creep capsules to be irradiated in the Advanced Teat Reactor (ATR) at Idaho National Laboratory (INL) in support of the Next Generation Nuclear Plant (NGNP). Since the AGC-1 capsule was first conceived [1] it has undergone a number of design changes, requiring a revision of the original layout [2]. Here we describe the post irradiation examination (PIE) of the AGC-1 creep specimens to be conducted in the Low Activation Materials Development and Analysis (LAMDA) facility at the Oak Ridge National Laboratory (ORNL). This experimental plan describes the testing to be performed on the graphite creep specimens and $\mathrm{SiC}$ monitors only.

\section{MATERIALS}

A full description of the materials/specimens contained in this experiment may be found in the "AGC-1 Experimental Plan" [1] and in "A Revised AGC-1 Creep Capsule Layout" [2]. The graphite to be examined here are the AGC-1 creep specimens listed in Table 1. The preirradiation data [3] and sister specimens testing data [4] have previously been reported.

Table 1 Graphite grades and marking codes used for the AGC-1 series of creep specimens

\begin{tabular}{|c|c|}
\hline Graphite Code Letter & Graphite Grade \\
\hline A & NBG-17 \\
\hline B & NBG-18 \\
\hline C & H-451 \\
\hline D & PCEA \\
\hline E & IG-110 \\
\hline F & IG-430 \\
\hline
\end{tabular}

The graphite grades examined here all are in compliance with the ASTM specification for nuclear graphite [5].

\section{MATERIAL POST-IRRADIATION EXAMINATION}

Post-irradiation examination (PIE) will follow the workflow chart in Figure 1. Following irradiation in ATR the AGC-1 capsule will cool in the ponds followed by shipment to the hot cells. The capsule is disassembled in the hot cells at INL and the specimens and temperature monitors recovered and shipped to the Low Activation Material Development \& Analysis (LAMDA) at ORNL. The specimens will undergo post irradiation examination (PIE) which will consist of visual inspection, dimensional measurements, creep strain, mass, and hence density, elastic constants (sonic velocity), dynamic Modulus by resonance frequency, electrical resistivity, and coefficient of thermal expansion. Additional microstructural characterization may be performed depending on schedule and budget. Fracture testing will also be conducted but the nature of testing (tensile, or compression) has not been determined at this time. 


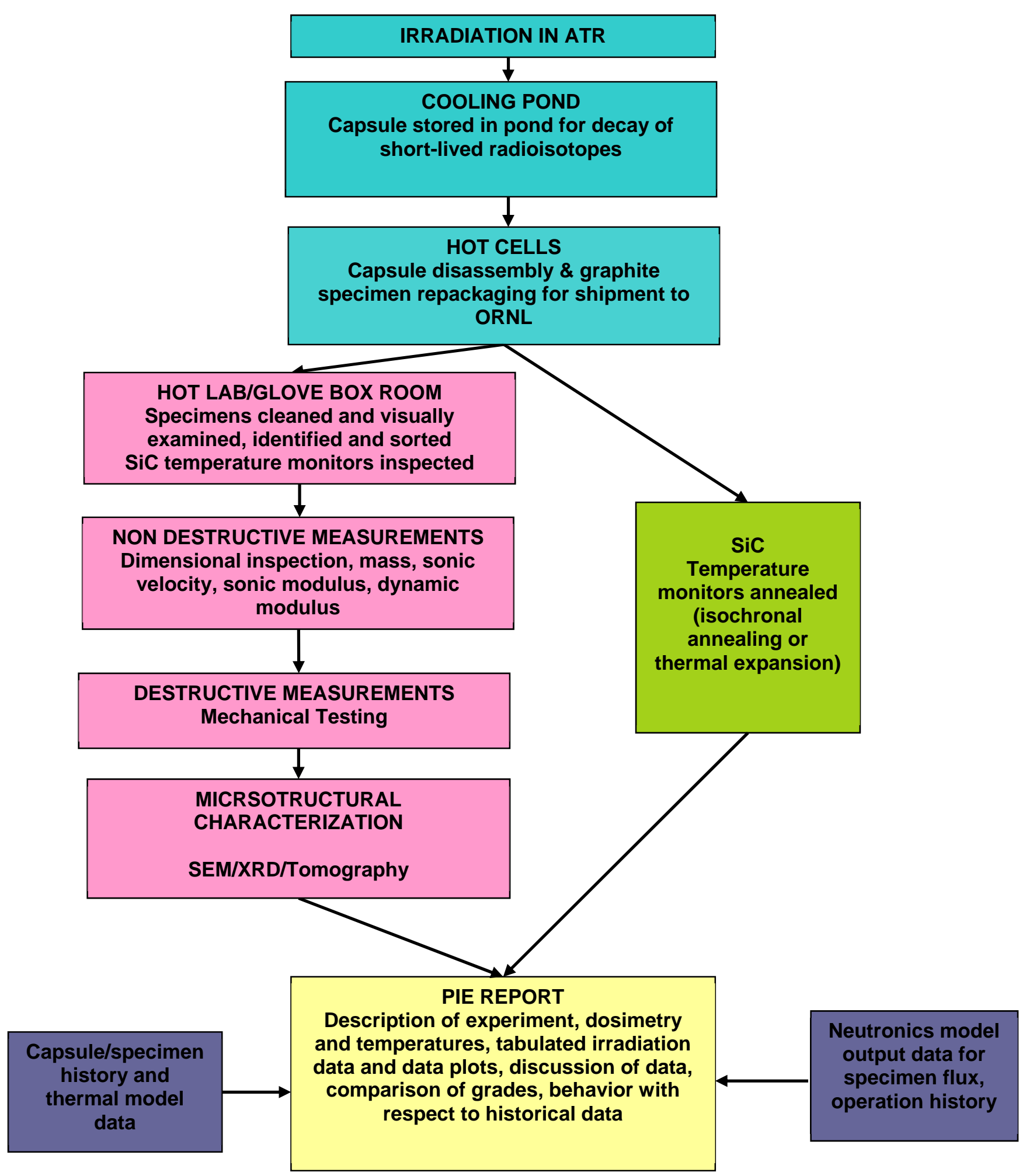

Figure 1 Post-irradiation data process flow chart for AGC-1 graphites 
The specimen irradiation temperature will be determined from temperature monitors encapsulated within the specimens (Figure 2) in the AGC-1 central channel. The SiC monitors will be retrieved by INL and shipped to ORNL for testing. The irradiation temperature will be estimated by either (i) isochronal annealing followed by electrical resistivity (ER) determination using ASTM C611 [6], or (ii) thermal expansion. A plot of resistivity as a function of annealing temperature should display a marked change in resistivity when the annealing temperature exceeds the maximum irradiation temperature. The second method involves the continuous measurement of thermal expansion, in accordance with ASTM E228 [7] as the monitor is heated to a temperature in excess of the irradiation temperature. Again, the expansion data should exhibit a change in gradient when the irradiation temperature is exceeded.

The isochronal annealing temperature schedule is reported in Table 2.

Table 2 Annealing schedule for SiC temperature monitors

\begin{tabular}{|c|c|c|c|}
\hline $\begin{array}{c}\text { Annealing } \\
\text { Temperature, }{ }^{\circ} \mathrm{C}\end{array}$ & $\begin{array}{c}\text { Heating Rate, } \\
{ }^{\circ} \mathrm{C} / \mathrm{min}\end{array}$ & $\begin{array}{c}\text { Time at } \\
\text { Temperature, } \\
\text { minutes }\end{array}$ & Actions \\
\hline 400 & 2.5 & 30 & Cool to RT, Measure ER \\
\hline 450 & 2.5 & 30 & Cool to RT, Measure ER \\
\hline 500 & 2.5 & 30 & Cool to RT, Measure ER \\
\hline 550 & 2.5 & 30 & Cool to RT, Measure ER \\
\hline 600 & 2.5 & 30 & Cool to RT, Measure ER \\
\hline 625 & 2.5 & 30 & Cool to RT, Measure ER \\
\hline 650 & 2.5 & 30 & Cool to RT, Measure ER \\
\hline 675 & 2.5 & 30 & Cool to RT, Measure ER \\
\hline 700 & 2.5 & 30 & Cool to RT, Measure ER \\
\hline 725 & 2.5 & 30 & Cool to RT, Measure ER \\
\hline 750 & 2.5 & 30 & Cool to RT, Measure ER \\
\hline 775 & 2.5 & 30 & Cool to RT, Measure ER \\
\hline 800 & 2.5 & 30 & Cool to RT, Measure ER \\
\hline 850 & 2.5 & 30 & Cool to RT, Measure ER \\
\hline 900 & 2.5 & 30 & Cool to RT, Measure ER \\
\hline
\end{tabular}

Isochronal annealing furnace runs will be heated at $2.5^{\circ} \mathrm{C} /$ minute, followed by a 30 minute dwell at temperature, cooled to room temperature and ER measured [6]. The experimental thermometry data will be contained in a final PIE report. Some of the SiC monitors were found broken on receipt from INL and thus were too short for ER measurement. These shorter monitors will be subjected to thermal expansion measurement. The $\mathrm{SiC}$ temperature monitors were heated at a rate of $2.5^{\circ} \mathrm{C} /$ minute to $1000^{\circ} \mathrm{C}$ while expansion was continuously measured according toE228 [7]. Table 3 indicates the $\mathrm{SiC}$ numbers, tube ID's, and the experimental measurements to be made. 
TOP OF Ftack UP

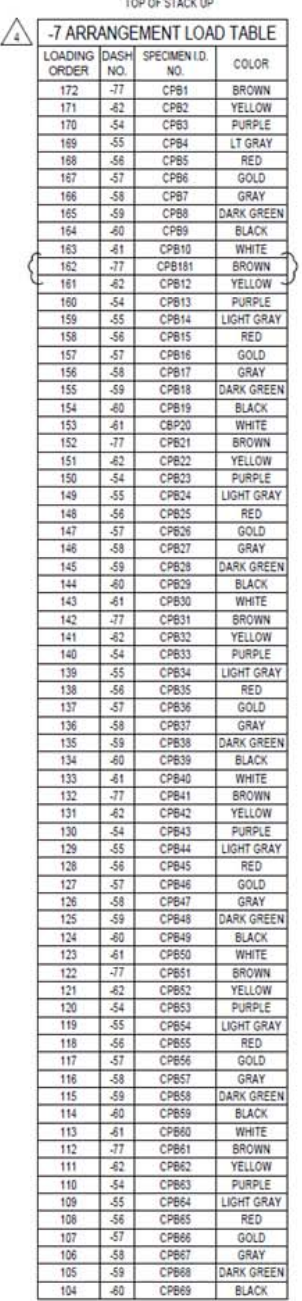

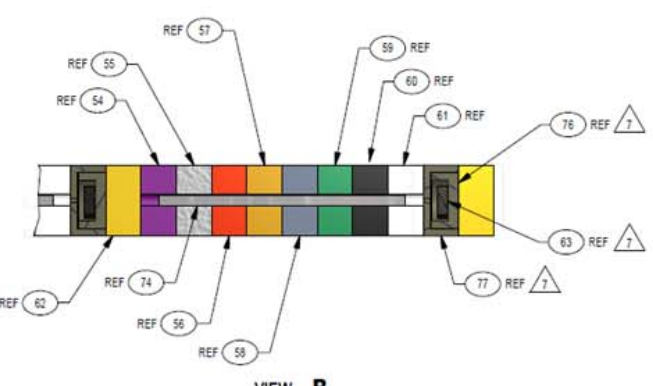

VIEW B

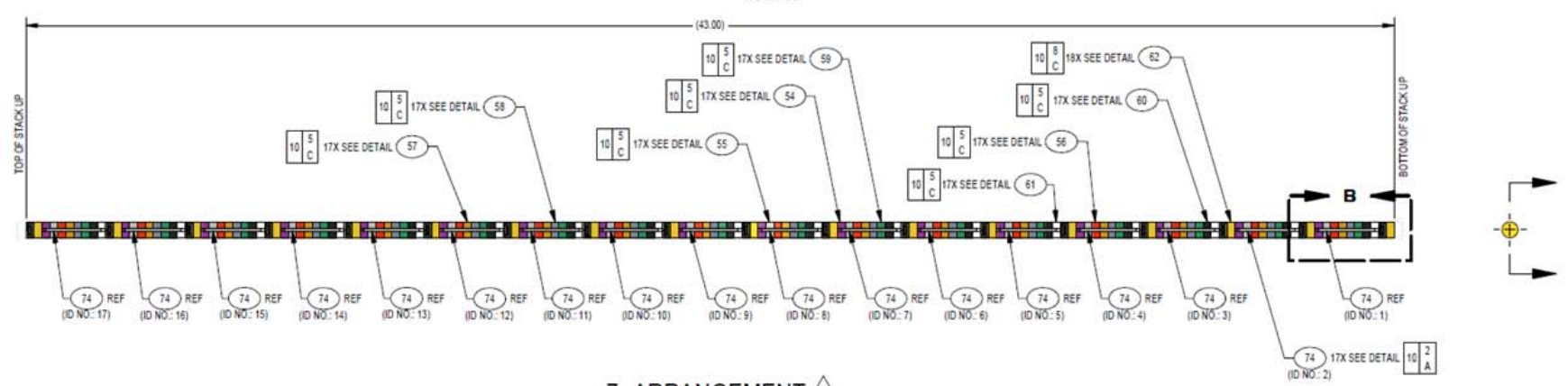

-7 ARRANGEMENT 2
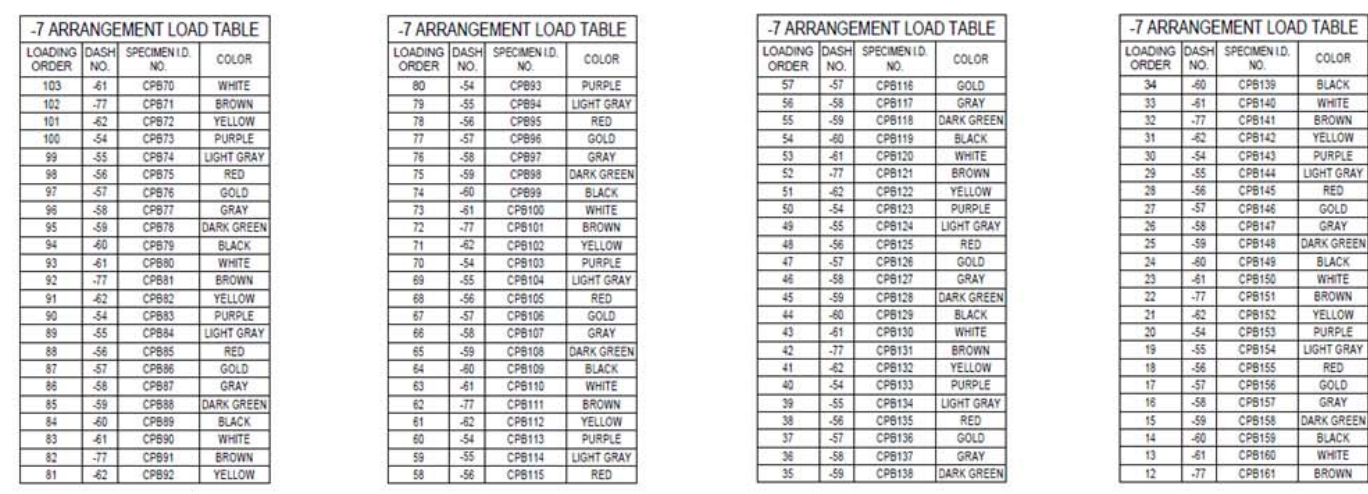

Figure 2 Drawing of AGC-1 capsule showing positions of SiC temperature monitors 
Table 3 SiC temperature monitor information from AGC-1 (10-26-11) as supplied by INL

\begin{tabular}{|c|c|c|c|}
\hline $\begin{array}{c}\text { Number on Plastic } \\
\text { Cryo Tube }\end{array}$ & $\begin{array}{l}\text { Piggy back specimen associated } \\
\text { with SiC TM in Plexiglass shipping } \\
\text { tube from MFC. }\end{array}$ & $\begin{array}{l}\text { SiC TM ID Number } \\
\text { per INL Dwg. } 630431 \\
\text { rev. } 3 .\end{array}$ & $\begin{array}{c}\text { Experimental } \\
\text { Measurement } \\
\text { Technique } \\
\end{array}$ \\
\hline 1 & CPB24 & 15 & Elec. Resist. \\
\hline 2 & CPB1-10 & 17 & Elec. Resist. \\
\hline 3 & CPB11-20 & 16 & Elec. Resist. \\
\hline 4 & CPB88 & 9 & Therm. Expan. \\
\hline 5 & CPB124, 125 & 5 & Therm. Expan. \\
\hline 6 & CPB76, 77, 79 & 10 & Therm. Expan. \\
\hline 7 & CPB156, 157 & 2 & Elec. Resist. \\
\hline 8 & CPB118, 119 & 6 & Elec. Resist. \\
\hline 9 & CPB167, 168 & 1 & Elec. Resist. \\
\hline 10 & CPB145, 144 & 3 & Elec. Resist. \\
\hline 11 & CPB110, 109 & 7 & Elec. Resist. \\
\hline 12 & CPB98, 99 & 8 & Elec. Resist. \\
\hline 13 & CPB68, 70 & 11 & Elec. Resist. \\
\hline 14 & CPB55, 57, 60 & 12 & Elec. Resist. \\
\hline 15 & СРВ49, 47 & 13 & Elec. Resist. \\
\hline 17 & $\begin{array}{c}\text { Packaged alone in bottle. By process } \\
\text { of elimination this is either ID no. } \\
14 \text { or } 4 \text { and therefore no. } 14 \text { or } 4 \text { are } \\
\text { missing. }\end{array}$ & 14 or 4 & Elec. Resist. \\
\hline
\end{tabular}




\section{EXERIMENTAL PIE METHODS}

The applicable ASTM test standards used here are listed in Table 4.

Table 4 Applicable ASTM test methods

\begin{tabular}{|c|c|c|c|}
\hline Test Property & Standard Title & $\begin{array}{c}\text { ASTM } \\
\text { Standard }\end{array}$ & $\begin{array}{l}\text { Ref } \\
\text { No. }\end{array}$ \\
\hline General & $\begin{array}{l}\text { Testing Graphite and Boronated Graphite Materials for High- } \\
\text { Temperature Gas-Cooled Nuclear Reactor Components }\end{array}$ & $\mathrm{C} 781$ & {$[8]$} \\
\hline $\begin{array}{l}\text { Dimensions, } \\
\text { mass, density }\end{array}$ & $\begin{array}{c}\text { Bulk Density by Physical Measurements of Manufactured Carbon } \\
\text { and Graphite Articles }\end{array}$ & C559 & [9] \\
\hline $\begin{array}{c}\text { Electrical } \\
\text { Resistivity }\end{array}$ & $\begin{array}{c}\text { Electrical Resistivity of Manufactured Carbon and Graphite } \\
\text { Articles at Room Temperature }\end{array}$ & C611 & {$[6]$} \\
\hline $\begin{array}{l}\text { Dynamic } \\
\text { Young's } \\
\text { Modulus } \\
\end{array}$ & $\begin{array}{c}\text { Moduli of Elasticity and Fundamental Frequencies of Carbon and } \\
\text { Graphite Materials by Sonic Resonance }\end{array}$ & $\mathrm{C} 747$ & {$[10]$} \\
\hline $\begin{array}{l}\text { Dynamic } \\
\text { Young's } \\
\text { Modulus }\end{array}$ & $\begin{array}{l}\text { Dynamic Young's Modulus, Shear Modulus, and Poisson's Ratio } \\
\text { for Advance Ceramics by Impulse Excitation of Vibration }\end{array}$ & C1259 & [11] \\
\hline $\begin{array}{l}\text { Yong's } \\
\text { Modulus }\end{array}$ & $\begin{array}{c}\text { Sonic Velocity in Manufactured Carbon and Graphite Materials for } \\
\text { Use in Obtaining Young's Modulus }\end{array}$ & C769 & [12] \\
\hline $\begin{array}{c}\text { Thermal } \\
\text { Expansion }\end{array}$ & $\begin{array}{c}\text { Linear Thermal Expansion of Thermal Materials with a Push-Rod } \\
\text { Dilatometer }\end{array}$ & E228 & [7] \\
\hline $\begin{array}{l}\text { Compressive } \\
\text { Strength }\end{array}$ & Compressive Strength of Carbon and Graphite & C695 & [13] \\
\hline $\begin{array}{c}\text { Tensile } \\
\text { Strength } \\
\end{array}$ & Tensile Stress-Strain of Carbon and Graphite & C749 & [14] \\
\hline $\begin{array}{l}\text { Glued End } \\
\text { Tensile } \\
\text { Strength }\end{array}$ & $\begin{array}{l}\text { Testing Graphite and Boronated Graphite Materials for High- } \\
\text { Temperature Gas-Cooled Nuclear Reactor Components }\end{array}$ & $\begin{array}{c}\text { C781 A4 } \\
\text { (mod to } \\
\text { C749) }\end{array}$ & [15] \\
\hline
\end{tabular}

The order of PIE testing shall be:

1. Visual inspection. photography

2. Dimensions, mass, density

3. Electrical resistivity

4. Dynamic Young's modulus by resonance

5. Sonic velocity and elastic constants

6. Thermal expansion, CTE

7. Strength

8. XRD, SANS, tomography, microscopy

Dimensional measurements will be taken according to the scheme in Figure 3 so as to assure complete repeatability from the pre-irradiation measurements. Similarly, specimen alignment (with respect to the engraved number) during PIE physical property measurements shall be the 
same as previously employed during Pre-IE [3]. Any testing limitations in regard of specimen size shall be in accordance with C781[8].

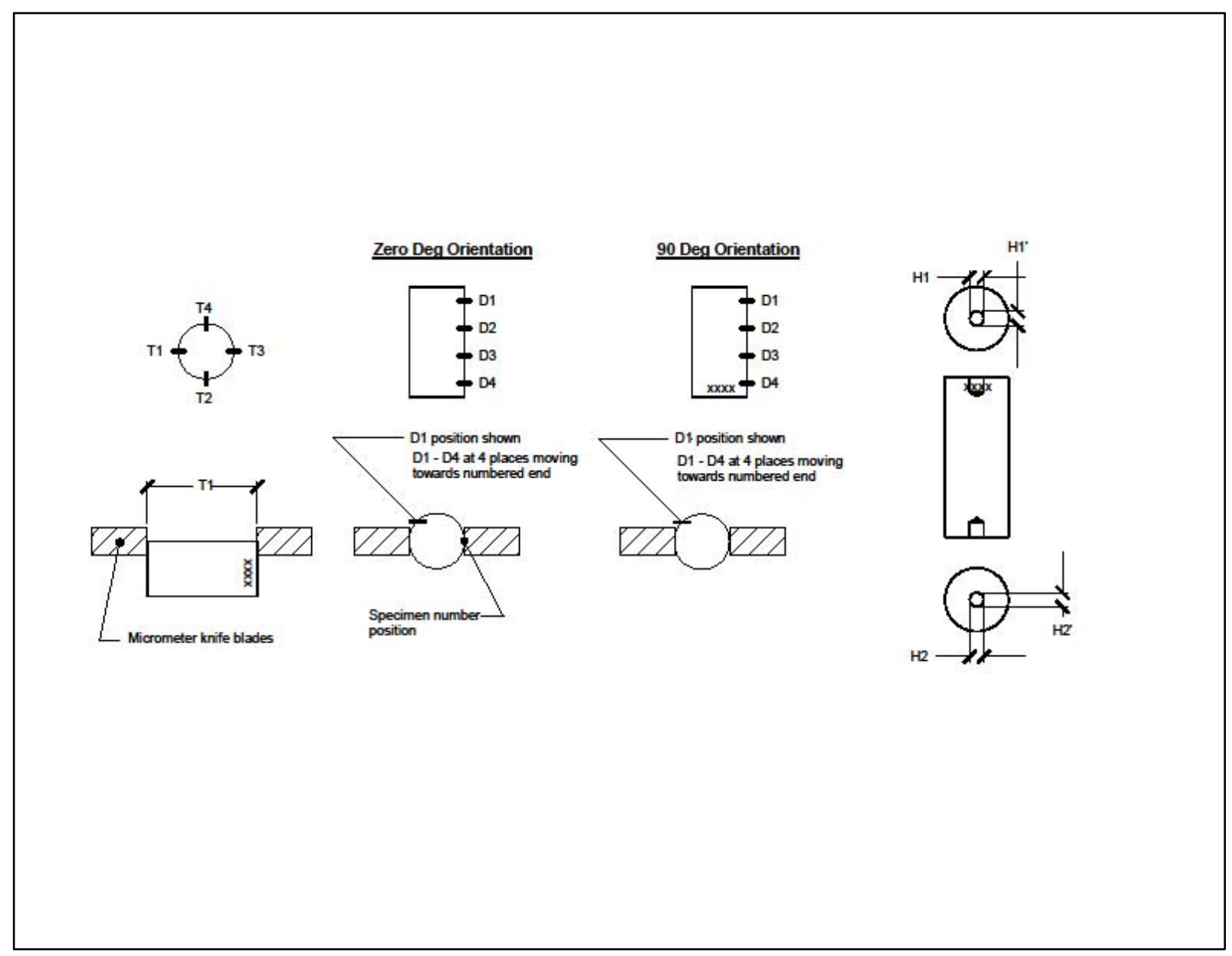

Figure 3 AGC-1 creep specimen measurement scheme

\section{QUALITY ASSURANCE}

The activities described in this plan will be conducted in accordance with the applicable requirements of the ASME/NQA-1-2000 national standard entitled Quality Assurance Requirements for Nuclear Facility Applications. Project and activity-specific information concerning ORNL's application of the standard's requirements is provided in Document \#QAPORNL-NGNP-01 entitled Quality Assurance Plan for the Next Generation Nuclear Plant Materials Program at Oak Ridge National Laboratory [15]. 
ORNL/TM-2012/70

\section{REFERENCES}

1. T. Burchell and R. Bratton, Graphite Irradiation Creep Capsule AGC-1 Experimental Plan, ORNL/TM-2005/505, Sept 2006. (revised and issued Sept 2006)

2. T. Burchell, A Revised AGC-1 Creep Capsule Layout, ORNL/TM-2009/009, Jan 2009, (revised and issued Nov. 2010)

3. T. Burchell, J Strizak, and M. Williams, AGC-1 Specimen Pre-irradiation Data Report, ORNL/TM-1010/285 (distributed Sept 2011)

4. T. Burchell, S. Nunn, J. Strizak, and M. Williams, AGC-1 Sister Specimen Testing Data Report, ORNL/TM-2009/025, May 2009 (distributed June 2009)

5. ASTM D7219 - 08, Standard Specification for Isotropic and Near-isotropic Nuclear Graphites, Annual Book of Standards, Vol. 05.05, 2012

6. ASTM C611 - 98, Standard Test method for Electrical Resistivity of Manufactured Carbon and Graphite Articles at Room Temperature, Annual Book of Standards, Vol. $05.05,2012$

7. ASTM E228 - 11, Standard Test Method for Linear Thermal Expansion of Solid Materials With a Push-Rod Dilatometer, Annual Book of Standards, 2012

8. ASTM C781 - 08, Standard Practice for Testing Graphite and Boronated Graphite Materials for High temperature Gas-Cooled Nuclear Reactor Components , Annual Book of Standards, Vol. 05.05, 2012

9. ASTM C559 - 90 (Reapproved 2010), Standard Test Method for Bulk Density by Physical Measurements of Manufactured Carbon and Graphite Article, Annual Book of Standards, Vol. 05.05, 2012

10. ASTM C747 - 93 (Reapproved 2010), Standard Test Method for Moduli of Elasticity and Fundamental Frequencies of Carbon and Graphite Materials by Sonic Resonance, Annual Book of Standards, Vol. 05.05, 2012

11. ASTM C1259 - 08, Standard Test for Dynamic Young's Modulus, Shear Modulus, and Poisson's Ratio for Advanced Ceramics by Impulse Excitation of Vibration, Annual Book of Standards, 2012

12. ASTM C769 - 09, Standard Text Method for Sonic Velocity in Manufactured Carbon and Graphite Materials for Use in Obtaining Young's Modulus, Annual Book of Standards, Vol. 05.05, 2012

13. ASTM C695 - 91 (Reapproved 2010), Standard Test Method for Compressive Strength of Carbon and Graphite, Annual Book of Standards, Vol. 05.05, 2012

14. ASTM C749 - 08 (Reapproved 2010), Standard Test Method for Tensile Stress-Strain of Carbon and Graphite, Annual Book of Standards, Vol. 05.05, 2012

15. QAP-ORNL-NGNP-01 (Rev2), Quality Assurance Plan for the Next Generation Nuclear Plant Materials Program at Oak Ridge National Laboratory, July 2009 
